\title{
Academic Motivation And Self-Regulated Learning In Predicting Academic Achievement In College
}

Baris Cetin, Ph.D., Canakkale 18 Mart University, Turkey

\begin{abstract}
The purpose of this study was to determine whether academic motivation and academic selfregulated learning predicted students' GPAs in the Early Childhood Education Department. The study participants consisted of 166 early childhood education majors enrolled in the 2014 spring semester at Georgia Southern University, USA. Data were gathered using the "academic motivation scale" developed by Vallerand et al. (1992), and the "academic self-regulated learning scale" developed by Mango (2010). The study's results showed that there was no correlation between GPA and academic motivation and academic self-regulation learning. In other words, the students' academic motivation and academic self-regulated learning total scores, together, did not predict their GPA.
\end{abstract}

Keywords: Early Child Education; Academic Motivation; Academic Self-Regulated Learning; Grade Point Average

\section{INTRODUCTION}

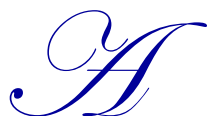

cademic achievement of university students is thought to be affected by variables including intelligence, readiness, attitude, studying habits, anxiety, health, thinking skills, self-competence, academic motivation, self-regulation learning to name but these few. In this study, academic motivation and academic self-regulated learning have been examined.

\section{Self-Regulated Learning}

According to the social cognitive theory, self-regulation is situational specific, which means that learners do not engage in self-regulation equally in all domains (Schunk \& Zimmerman, 2003). Studies on self-regulated learning emerged in the mid 1980's (Zimmerman, 2001). Self-regulatory includes self-monitoring, which involves observing one's own performance and output (Zimmerman \& Kitsantas, 2005). According to Zimmerman and Schunk (1989), self-regulated learning can be defined in terms of self-generated thoughts, feelings, and actions, which show a systematical tendency to attain one's goals. According to Winne (1995), self-regulated learning is a constructive and self-directed process.

Self-regulatory is the process of transforming one's intelligence into academic skills, guiding it to self. Selfregulatory takes result oriented behavior and ideas that it creates on its own as reference. Self-regulatory is significant because the purpose of education is to enhance lifelong learning skills. After graduating from high school or university, young adults can learn very important abilities through unofficial ways (Zimmerman, 2002). Self-regulatory includes strategic performance adjusting processes and self-monitoring (Zimmerman, 2010).

The structure and function of self-regulatory process consists of the performance phase, self-reflection phase and forethought phase (Zimmerman, 2002; Zimmerman \& Kitsantas, 2005; Zimmerman \& Schunk, 2004; DiBenedetto \& Zimmerman, 2013). Performance phase consists of self-control and self-observation phases, and takes the specific method chosen at self-control precaution phase as reference. Self-observation takes self-testing as reference in order to find out the reasons for self-recording (Zimmerman, 2002). Self-observation includes self- 
directed interest (Zimmerman, 1994). Self-observation is affected by behavioral effects as well as personal processes, composed of metacognition planning, purpose composing and self-competence (Zimmerman, 1989). Selfobservation" corresponds to metacognitive monitoring or record keeping of one's performance, the relevant conditions related to such performance, and the effects that it results in (Zimmerman \& Paulsen, 1995; cite by Zimmerman \& Kitsantas, 2005). Self-observation involves recording the frequency, intensity, or quality of behavior. Self-observation is crucial in determining one's progress. In the absence of self-observation, selective memory of successes and failure become activated. Self- observation may lead to increased motivation because when people realize what they do, they may change their behavior (Pintrich \& Schunk, 2002).

The self-reflection phase, which forms the structure of self-regulatory process, consists of self-judgment and self-reaction phases. Self-judgment takes the comparison of self-observation performances under certain circumstances (Zimmerman, 2002). Self-judgment affects the importance of goal achieving and its purpose features (Zimmerman, 1994). Self-judgment takes the comparison between one's purpose and present performance as reference (Schunk, 1994; Schunk, 1989). Self-judgment includes self-evaluation by attributing temporal importance to the individual's performance and results (Zimmerman, 2012). Self-judgment means comparing present performance with one's goal. If a person believes that he/she is making goal progress, self-efficacy increases and motivation sustains. Students who consider a task to be easy may think that they set their goal too low and set their subsequent goal higher. If one knows that similar others performed a task, one can reach increased levels of self-efficacy and motivation (Schunk, 1987).

Self-judgments refer to evaluating one's learning performance and attributing causal significance to the outcomes. Students who are highly regulated self-evaluate themselves in a more appropriate way and more frequently compared to those who are poorly regulated (Lan, 1998; cite by Zimmerman \& Kitsantas, 2005). Getting results by self-judgment and the importance of purpose attribution depends on the specifics of purpose and following selfevaluation standards (Schunk, 2008). Self-judgment may become affected by the specifics of the purpose, the significance of failing and contributions to one's performance (Schunk, 1989).

Self-reaction involves taking one's performance into consideration and feelings of self-satisfaction (Zimmerman, 2002). Self-reaction involves attribution of learners for performance as well as evaluation of learners' performance and judgment over tasks (Pintrich, 2010). Self-reaction includes one's cognitive, emotional and selfjudging behavioral reactions (Zimmerman, 1994). Self-reactions to goal progress have effects on motivation (Bandura, 1986; cite by Pintrich \& Schunk, 2002). Students who judge their goal progress to be acceptable would find themselves efficacious about continuing to improve and be motivated. If students believe that they can improve their performance, negative evaluations may not decrease their motivation. Motivation does not increase when students believe they do not have the ability to improve (Schunk \& Zimmerman, 2003). Self-reactions are behavioral, cognitive, and emotional responses to self-judgments. Believing that one is making good progress and the anticipation of satisfaction regarding accomplishing a goal increases the level of self-efficacy (Pintrich \& Schunk, 2002).

Forethought phase is separated into two as self-motivation beliefs and task (Zimmerman, 2002). Forethought phases prepare for individuals' learning (Zimmerman \& Kitsantas, 2005). Task analysis includes goal setting and strategic planning (Zimmerman, 2002; DiBenedetto, \& Zimmerman, 2013). Self-motivation originates from one's beliefs about learning, such as self-efficacy beliefs about having the capability to learn and outcome expectations about consequences of learning (Bandura, 1997). Self-motivational beliefs include self-efficacy, outcome expectations, task value, and goal orientation (Zimmerman, 2002; DiBenedetto, \& Zimmerman, 2013). Reflecting, control and reaction occur simultaneously in self-regulated learning (Pintrich, 2004).

Uses of self-regulated learning strategies by students render them capable of increasing personal control over their own environments. Self-regulated learning provides the gaining of self-competence senses and may explain the student's connection to motivation and achievement (Zimmerman, 1989). Self-regulated learning processes do not just enrich motivation, but also predict outstanding academic and athletic achievement (Zimmerman \& Kitsantas, 2005). Self-regulated learning strategies include organization and transformation, data research, record keeping, selfobservation, environmental structuring, self-effectuating, repeating, memory, surveying, and social aid (Zimmerman, 1990).

\section{Academic Motivation}


Motivation theories are founded on assumptions about the human nature (Deci \& Ryan, 1985). The concept of motivation takes maintaining and guiding behaviors and innate strengths as reference (Petri, 1981; cited by Vallerand \& Losier, 1994). Deci and Ryan (1985) separated motivation into three categories: amotivation, extrinsic motivation and intrinsic motivation (Deci \& Ryan, 2002).

Amotivation is strongly and negatively related to educational outcomes (Vallerand \& Bissonnette, 1992). Amotivation involves not having a motive to act (Williams \& Deci, 1996). Amotivation takes the lack of motivation and the observation of the individual's inability to sense the conditions between his or her actions and consequences as reference (Ratelle, Guay, Vallerand, Larose, \& Sene'cal, 2007). Not being able to self-determine or be competent with regard to a specific behavior results in amotivation, which is accompanied by helplessness, depression, and selfdisparagement. Amotivation occurs when a person cannot get positive feedback regarding his/her performance or believes that he/she fails on a repetitive basis. According to the revised theory of helplessness, noncontingent environments lead to amotivation. On the other hand, if the person learns how to retake control or can rationalize such conditions, motivation will be intact. In sum, decreased perceived control leads to amotivation and helplessness. Amotivation results when one perceives oneself as incompetent to reach intended outcomes (Deci \& Ryan, 1985).

A person engages in intrinsically motivated behaviors in order to feel competent and self-determining. The primary effects of such behaviors involve the tissues of the central nervous system. There are two general types of intrinsically motivated behaviors. A stimulation free environment would lead one to feel incompetent and not selfdetermining and therefore to seek out ways for feeling competent and self-determining. The other type of intrinsically motivated behavior involves conquering challenges or reducing incongruity (Deci, 1975). Intrinsic motivation is a source that is central to the nature of the organism. Intrinsic motivation depends on the innate need for competence and self-determination. It provides the fuel for various behaviors and psychological processes. Intrinsic needs are different from primary drives because they are not based in tissue deficits and they do not function cyclically. However, both of them are innate and provide an energy source for behavior. In addition, intrinsic motivation can increase or decrease the intensity of drives and also influence the way one satisfies his/her drives (Deci \& Ryan, 1985). Extrinsic motivation is separated into four categories four as external regulation, introjected regulation, identified motivation and integrated regulation (Deci \& Ryan, 2002).

External regulation occurs when the behavior is formed externally (Vallerand \& Bissonnette, 1992). External regulation occurs when students relate results in order to control for the function of time and rewards they attribute to learned activities (Zimmerman, 2012). The least autonomous type of extrinsic motivation is external regulation, which involves being motivated to obtain rewards or avoid punishments. External regulation has an external perceived locus of causality (Skinner, 1953; cite by Deci\& Ryan, 2002).

Introjected regulation refers to an internalized external regulation but which is not truly accepted as one's own. It is some form of partially internalized extrinsic motivation. Introjection is a type of internalized regulation and is very controlling. Introjection-based behaviors are performed in order to avoid guilt or to produce ego enhancements and feelings of worthiness. This type of regulation depends on contingent self-esteem (Deci \& Ryan, 1995; Cite by Deci \& Ryan, 2002).

Regulation through identification is a more self-determined form of extrinsic motivation, since it includes valuing of a behavioral goal or regulation. Identification is important in transforming external regulation into true selfregulation. Identification is accompanied by high-perceived autonomy. Identifications seem to have an internal perceived locus of causality (Deci, \& Ryan, 2002). Identification is the process of specification of an activity by its value and this way an acceptable regulation of one's dynamism is taken as reference (Vansteenkiste, Lens, \& Deci, 2006). Identification is the self-definition of external motivation and contains the awareness value of behavioral purposes (Deci \& Ryan, 2002). As behavioral regulation leads to greater autonomy, people engage in behaviors due to the importance and value that they attribute to them. This type of self-regulation has an internal perceived locus of causality and is autonomous (Niemiec, Ryan \& Deci, 2010).

Integrated regulation is the basis for the most autonomous form of extrinsically motivated behavior. Integrated regulation results when identifications have been assessed and brought into congruence with the personally 
endorsed values, goals, and needs that are part of the self. Previous studies showed that integrated extrinsically motivated behaviors are associated with more positive experiences than the less fully internalized forms of extrinsic motivation. Integrated extrinsic motivation and intrinsic motivation have many similarities (Deci, \& Ryan, 2002). Integration of external motivation is mostly internal and integration occurs when individuals relate to their own schematics and their own activities (Zimmerman, 2012). Integration takes completing internalization as its reference and is the most proper form of internalization (Williams \& Deci, 1996).

Sensation of internal motivation is an important precursor of self-learning. Students who are bound for internal purposes in an experimental manner are more assertive than students who are bound for deep learning, good performance and external purposes (Vansteenkiste, Simons, Lens, Sheldon, \& Deci, 2004). Self-determination strengthens the feelings that enrich feelings of skill and feedback internal motivation (Deci, 1972; Deci, 1973). Intrinsic motivation takes individual's interest, pleasure and his or her satisfaction with a task or an activity as reference (Zimmerman, 2011). Internal motivation involves people participating in an activity (Gagné \& Deci, 2005). Internal motivation is the energy source, which centers the organism's active nature. Internal motivation is an important motivator of abilities, which characterize human development and learning (Deci \& Ryan, 1985). Internal motivation essentially affects central nervous system tissues rather than tissues outside the nervous system (Deci, 1975).

According to the self- determination theory, supporting all three psychological needs helps with the internalization process. However, conflict between needs, such as letting go of autonomy in order to socialize and receive approval and acceptance, has negative effects on behavioral regulation and well being (Assor, Roth \& Deci, 2004). Self-determination refers to choosing between alternatives and the experience of an international perceived locus of causality. Self-determination is an important part of intrinsically motivated behavior and also of some extrinsically motivated behaviors. Self-determination is also a need. It facilitates developing competencies and reaching a flexible accommodation with the social environment, which is central to the development of extrinsic motivation (Deci \& Ryan, 1985). In order to self-determine, one should accept his or her strengths and limitations, make choices, and determine the ways of satisfying needs. Will and self-determination are associated because, in order to be self-determining, people have to decide how to act on their environment and they would not prefer a condition where all of their needs are instantly satisfied without them making choices (Pintrich \& Schunk, 2002).

Self-determination theory is a concept included in intrinsic motivation. Self -determination theory takes the experience of freedom inside one's commencing behavior as reference. The pressure caused by the condition of strengthening and any other pressure is decisive on one's actions. Self-determination often includes results or one's environmental control and choices (Deci \& Ryan, 1985). Self-determination theory takes personal growth, selfarrangement, global psychological needs, purpose of living, longings, energy and validity, unaware periods, cultural relations for motivation, and effects of motivation on social environments as reference (Deci \& Ryan, 2008). Selfdetermination theory offers relatively more autonomy supplying social content or enriches internal motivation (Vansteenkiste et al., 2006). High motivation may enhance students' learning processes and results, interest, choosing of a task, efforts to learn a hard task and patience (Zimmerman, 2012).

\section{The Relationship Between Motivation And Self-Regulation Learning}

Motivational control and the process of regulation lead to positive conditioned results on academic performance (Schunk, 2005). Self-regulation learning is related to motivation (Schraw, Crippen, \& Hartley, 2006; Schunk \& Ertmer, 2010; Pintrich, 2010; Zimmerman, 2010; Zimmerman \& Schunk, 2004). Self-regulation increases learning and maintains motivation (Schunk \& Ertmer, 2010). Motivation predicts self-regulation (Schunk, 2008). School belonging, affective response, affective motivation, cognitive resources, and self-regulation are associated with academic achievement (Baumeister \& Leary, 1995, cite by Anderman \& Freeman, 2004). There is a significant relationship between motivation and self-regulated learning (Mahmoodi, Kalantarib \& Ghaslanic, 2014).

The Relationship Of Academic Achievement To Self-Regulated Learning And Academic Motivation 
Ekhlas and Shangarffam (2013) found correlations between academic self-regulated strategies and reading, writing, speaking, listening, and language experience. Heikkilä and Lonka (2006) detected a low positive relationship between academic average and self-regulated learning. Carolina, Lucia and Rossana (2014) determined that selfregulated learning and motivation had positive effects on academic achievement. Rytkonen, Parpala, LindblomYlanne, Virtanen, and Postareff (2012) demonstrated that social support and self-regulation skills are important for academic achievement. Gaythwaite (2006) found a significant relationship between final scores and self-regulated learning. Amrai, Motlagh, Zalani, and Parhon (2011) detected a correlation between academic achievement and motivation. Özder and Motorcan (2013) found a significant correlation between academic motivation and academic achievement. McGhee (2010) determined a low negative correlation between motivation and academic achievement. Lavender (2005) found a significant correlation between extrinsic motivation external regulation, which is one of the sub factors of academic motivation scale, and academic achievement.

Önder, Beşoluk, İskender, Masal, and Demirhan (2014) determined that academic motivation has a significant effect on academic achievement. Cokley, Bernard, Cunningham, and Motoike (2001) found significant correlations between GPA and the amotivation, intrinsic motivation to know, intrinsic motivation to achieve, and intrinsic motivation to experience stimulation sub factors. Robinson (2003) detected a positive correlation between intrinsic motivation to achieve and achievement and a negative correlation between amotivation and achievement. Lavender (2005) found a significant relationship between academic achievement and the amotivation sub factor of the academic motivation scale. Kosnin (2007) detected a significant correlation between academic achievement and selfregulated learning. Ning and Downing (2012) determined that self-regulation and motivation have minor regulating effects on the relationship between academic performance and learning experiences.

\section{Prediction Of Academic Achievement By Self-Regulated Learning And Academic Motivation}

Ekhlas and Shangarffam (2013) found that academic self-regulated learning strategies predicted $17.5 \%$ of the variance in IELTS reading skills. Kim and Seo (2013) showed that self-regulated learning explained academic achievement. Komarraju, Karau, and Schmeck (2009) determined that the best predictors of achievement are amotivation and intrinsic motivation to accomplish. Robinson (2003) found that the intrinsic motivation, extrinsic motivation and amotivation subscales of the academic motivation scale explained $8 \%$ of the variance in academic achievement. Kosnin (2007) determined that self-regulated learning is the best predictor of academic achievement in college students. Also, student motivation was the strongest predictor of academic performance (Kosnin, 2007; cited by Ning \& Downing, 2012).

Purpose

The aim of this study was to determine whether there were significant relationships between Early Childhood Education students' GPAs and their academic motivation, academic self-regulated learning and related subscales and to investigate whether academic self-regulated learning and its sub factors together significantly predict students' GPAs.

\section{Participants}

A total of 166 students (158 female and 8 male; 86 juniors and 80 seniors) who study at Georgia Southern University in the United States of America College of Education, Teaching and Learning Department, in the Early Childhood Education program participated in the study.

\section{METHOD}

Prediction studies are conducted in order to determine the prediction of instruments' validity, to help with different types of choosing, and to implement decisions regarding individuals (Gay, Mills, \& Airasian, 2009). A prediction study is used as a different design in correlation research and examines the correlations between variables (Lodico, Spaulding, \& Voegtle, 2010). Prediction studies show how a variable is predicted by other variable using correlation coefficients (McMillan, 2008). The model of this study is a prediction study since it was aimed to determine 
predictive relationships of academic motivation and academic self-regulated learning together for Early Childhood Education students' GPAs.

\section{Materials}

Academic Motivation Scale

The scale includes 28 items and 7 factors, each factor includes 4 items, and each item has 7 response categories. The scale consists of 3 intrinsic motivation factors, 3 extrinsic motivation factors, and one factor of amotivation. These factors are intrinsic motivation - to know, intrinsic motivation - toward accomplishment, intrinsic motivation - to experience stimulation, extrinsic motivation - identified, extrinsic motivation - introjected, extrinsic motivation - external regulation and amotivation. Scores obtained from the sub factors range between 4 and 28 and there are no reverse scored items in the scale. The reliability coefficients of the sub factors range from .71 to .83 and the Cronbach's alpha values of the sub factors change between .78 and .90 (Vallerand et al., 1992).

\section{Academic Self-Regulated Learning Scale}

The scale was developed by Magno (2010) in order to measure the self-regulation skills of university students in higher education and contains 54 items and 7 factors. Each item has 4 response categories. The sub factors of the scale are memory strategy (14 items), goal setting (5 items), self-evaluation (12 items), seeking assistance ( 8 items), environmental structuring ( 5 items), learning responsibility (5 items), and organizing (5 items). The construct validity of the scale was examined and the consistency reliability values of the sub factors were found to be between .73 and .87. It was determined that all sub factors showed significant correlations to each other and the correlation coefficients ranged between .25 and .55 (Mango, 2011).

\section{Procedures}

Data were gathered by administering the "Academic Motivation Scale", the "Academic Self-Regulated Learning Scale" and the "Personal Information Form" face-to-face to the Participants. Data were also collected from 12 fourth year students enrolled in the same semester by administering the "Academic Motivation Scale", the "Academic Self-Regulated Learning Scale" and the "Personal Information Form" via the Qualtrics (Online Research Surveys), which is utilized by Georgia Southern University in the United States of America. Multiple regression is essentially used to predict the relationship between two or more predictor variables and a criterion variable (Fraenkel $\&$ Wallen, 2006). Therefore, multiple regression analysis was used in the study. Pearson correlation analysis was used for determining the relationship of GPA to scores obtained from the "Academic Motivation Scale" and the "Academic Self-Regulated Learning Scale"; whereas multiple regression analysis was used for determining whether the "Academic Motivation Scale" and the "Academic Self-Regulated Learning Scale" together predict GPA.

\section{Grade Point Average}

The GPA corresponds to the general average of all course grades in $4^{\text {th }}$ and $5^{\text {th }}$ semester among junior students and $6^{\text {th }}$ and $7^{\text {th }}$ semester among senior students studying at Georgia Southern University, College of Education, in the Early Childhood Education program.

\section{Personal Information Form}

Data on GPA was collected according to the students' self-report. The form consists of questions about GPA, gender, and year of study. 


\section{RESULTS}

In this section, the results of the Pearson Product-Moment Correlation, which was carried out in order to determine whether there are significant correlations between early child education students' academic motivation and academic self regulation learning and GPSs, are provided. In addition, results of the multiple regression analysis, which was conducted for determining whether early child education students' academic motivation and academic self -regulation learning together predict GPAs, are given.

Table 1. Means And Standard Deviations Of Academic Motivation And GPA

\begin{tabular}{lccc}
\hline & $\mathbf{N}$ & Mean & Standard deviations \\
\hline GPA & 166 & 3.3300 & .41 \\
Intrinsic motivation to know & 166 & 3.6205 & .94417 \\
Intrinsic motivation accompishment & 166 & 3.4036 & .97221 \\
Intrinsic motivation to experience stimulation & 166 & 2.5964 & 1.08421 \\
Extrinsic motivation identified & 166 & 4.4639 & .58921 \\
Extrinsic motivation introjected & 166 & 4.0181 & .88402 \\
Extrinsic motivation external regulation & 166 & 4.1446 & .77276 \\
Amotivation & 166 & 1.2169 & .58358 \\
Academic motivation total score & 166 & 3.3253 & .58483 \\
\hline
\end{tabular}

Table 2. Means and standard deviations of academic self-regulated learning, and GPA

\begin{tabular}{lccc}
\hline & $\mathbf{N}$ & Mean & Standard deviations \\
\hline Memory strategy & 166 & 3.7831 & .61394 \\
Goal setting & 166 & 4.5120 & .61039 \\
Self-evaluation & 166 & 3.9940 & .62762 \\
Seeking assistance & 166 & 3.8494 & .72712 \\
Environmental structuring & 166 & 3.7831 & .73934 \\
Learning responsibility & 166 & 3.8976 & .75180 \\
Organizing & 166 & 4.0783 & .64188 \\
Academic self regulated learning total score & 166 & 3.9157 & .53268 \\
\hline
\end{tabular}

The relationship of GPA to academic motivation and academic self-regulated learning

Table 3. Correlation of GPA to academic motivation and academic self-regulated learning

\begin{tabular}{|c|c|c|c|c|c|c|c|c|c|}
\hline & 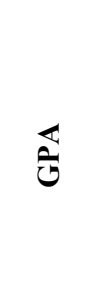 & 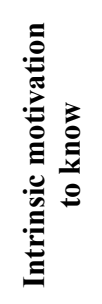 & 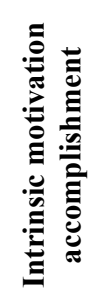 & 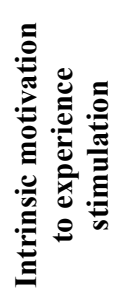 & & 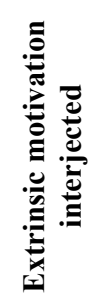 & 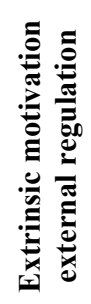 & 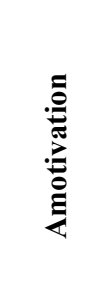 & 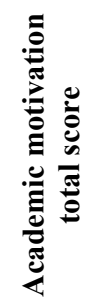 \\
\hline GPA & 1 & .017 & .028 & -.045 & .053 & .046 & .019 & -.169 & -.017 \\
\hline Memory strategy & -.031 & $.213^{* *}$ & $.340^{* *}$ & $.195^{*}$ & .129 & $.197^{*}$ & .118 & $-.003^{* *}$ & $.299^{* *}$ \\
\hline Goal setting & $.250^{* *}$ & .097 & .109 & .094 & $.212^{* *}$ & $.162^{*}$ & $.099^{* *}$ & -.092 & .176 \\
\hline Evaluation & -.052 & .139 & $.292^{* *}$ & $.192^{*}$ & .057 & $.262^{* *}$ & .052 & -.013 & $.286^{* *}$ \\
\hline Seeking assistance & -.122 & .119 & $.207^{* *}$ & .084 & .122 & $.202^{* *}$ & .071 & .149 & $.216^{* *}$ \\
\hline $\begin{array}{l}\text { Environmental } \\
\text { structuring }\end{array}$ & .005 & .064 & .106 & .064 & $.177^{*}$ & .071 & -.072 & .025 & .136 \\
\hline Learning responsibility & -.008 & $.167^{*}$ & $.214^{* *}$ & $.224^{* *}$ & .039 & .121 & -.035 & $.051^{* *}$ & $.319^{* *}$ \\
\hline Organizing & -.020 & $.229^{* *}$ & $.299^{* *}$ & $.290^{* *}$ & $.176^{*}$ & $.179^{*}$ & .653 & .510 & .000 \\
\hline ASRL total score & -.058 & $.213^{* *}$ & $.312^{* *}$ & $.245^{* *}$ & .125 & $.235^{* *}$ & .045 & $.059^{* *}$ & $.264^{* *}$ \\
\hline
\end{tabular}

*. Correlation is significant at the 0.05 level (2-tailed).

**. Correlation is significant at the 0.01 level (2-tailed). 
Table 3 showed that "goal setting", which is one of the academic self- regulation learning sub factors, was correlated to GPA $(\mathrm{P}<0.01)$ whereas GPA was not correlated to academic motivation and academic self-regulation learning. Academic motivation was also correlated to academic self regulation learning $(\mathrm{p}<0.01)$.

Prediction of GPA by academic motivation and academic self-regulated learning

Table 4. Results Of The Multiple Regression Analysis Regarding The Prediction Of Gpas By Academic Motivation And Academic Self-Regulated Learning Levels

\begin{tabular}{|c|c|c|c|c|c|}
\hline Variable & $\mathbf{B}$ & Standard Error B & $\mathbf{B}$ & $\mathbf{t}$ & $\mathbf{p}$ \\
\hline (Constant) & 3.063 & .381 & & 8.050 & .000 \\
\hline Intrinsic motivation to know & -.008 & .057 & -.017 & -.134 & .894 \\
\hline Intrinsic motivation accompishment & .066 & .057 & .156 & 1.164 & .246 \\
\hline Intrinsic motivation to experience stimulation & -.042 & .043 & -.110 & -.987 & .325 \\
\hline Extrinsic motivation identified & -.030 & .069 & -.043 & -.436 & .663 \\
\hline Extrinsic motivation introjected & .042 & .049 & .091 & .856 & .393 \\
\hline Extrinsic motivation external regulation & .021 & .051 & .039 & .416 & .678 \\
\hline Amotivation & -.085 & .060 & -.120 & -1.419 & .158 \\
\hline Academic motivation total score & -.061 & .113 & -.087 & -.542 & .589 \\
\hline Memory strategy & -.012 & .066 & -.018 & -.186 & .852 \\
\hline Goal setting & .225 & .058 & .333 & 3.898 & .000 \\
\hline Self-Evaluation & -.076 & .074 & -.115 & -1.027 & .306 \\
\hline Seeking assistance & -.078 & .055 & -.137 & -1.428 & .155 \\
\hline Environmental structuring & .013 & .054 & .024 & .246 & .806 \\
\hline Learning responsibility & .035 & .058 & .064 & .606 & .545 \\
\hline Organizing & .029 & .064 & .045 & .455 & .650 \\
\hline Academic self regulated learning total score & -.079 & .111 & -.102 & -.712 & .478 \\
\hline
\end{tabular}
$\mathrm{R}=.380, \mathrm{R}^{2}=.145, F(16-149), p>.082$

Table 3 showed that academic motivation and academic self-regulated learning total scores together did not predict students' GPAs at a significant level $\left(\mathrm{R}=.380, \mathrm{R}^{2}=.145, \mathrm{p}>.082\right)$. Total scores obtained from the academic motivation and academic self-regulated learning scales together explain $15 \%$ of the variance in GPAs. When we examined the t-test results regarding the significance of regression coefficients, we observed that only the goal setting sub factor had significant predictive power on students' GPAs and that the remaining variables did not have any significant effects.

\section{DISCUSSION}

Students' academic self-regulation total scores and academic motivation are not correlated sufficiently to GPA. The study result that supports this finding is as follows; Motivation was not correlated with academic achievement (Schmidt, Sczinski \& Ballard, 2006). There was only a correlation between "goal setting", which is one of the sub factors of academic self-regulation learning and GPA. It was found that "goal setting", which is a sub factor of the academic self- regulation scale, was positively correlated to the students' academic achievement. It is thought that goal setting is an important determinant of the students' academic performance. The reason of the lack of a significant correlation between academic self-regulated learning, academic motivation and GPA is thought to be the students GPAs being too close to each other. Another reason for the insignificant correlation between GPA and academic self-regulated learning is the variety and multitude of the possible factors affecting GPA. A correlation between self-regulation and motivation has been reported in the literature, this study determined such findings. In the literature, a relationship between motivation and self- regulated learning was reported (Schraw et al., 2006; Schunk \& Ertmer, 2010; Pintrich, 2010; Zimmerman, 2010; Zimmerman \& Schunk, 2004). The results of the present study are in parallel with the literature.

Students' academic motivation and academic self-regulation total scores and sub factors do not predict their GPAs at a significant level. Solely, the "goal setting" sub factor is a significant predictor of GPA. While academic motivation and academic self-regulation significantly predicted GPA in the literature, this study determined opposite results. Many factors have been thought to affect the prediction of GPAs. In this study, factors such as intelligence, reasoning skills, attitude, voluntarily choosing of the department being studied at, and studying habits have been 
thought to have an effect on GPA. In addition, students GPAs being too close to each other has been evaluated as the reason for the lack of significant prediction of GPAs by academic motivation and academic self-regulated learning. The education program provided for the students increased their levels of academic motivation and academic selfregulation learning, which caused their scores to be similar. Therefore, it is assumed that the effects of academic motivation and academic self regulation learning on academic achievement have decreased.

The results obtained through this research aimed to provide a resource for researchers of the teaching education field. The administrators, college of education scholars, and the authorities at a department of education as references to improve the quality of teacher education can use these results.

- It can be investigated whether Georgia Southern University in the United States of America College of Education, College of Education, Early Childhood Education Department's junior and senior students' academic motivation and academic self-regulation learning predict academic achievement at course level.

- It can be investigated whether academic motivation and academic self-regulation learning predict GPAs in junior and senior students who study at other Early Childhood Education programs throughout the United States.

\section{AUTHOR INFORMATION}

Barış Çetin, Ph.D., Department of Elementary Education, Canakkale 18 Mart University Turkey. For information about the work described in this article correspondence should be addressed to: Barış Çetin, Ph.D. Canakkale 18 Mart University, Department of Elementary Education, Canakkale, Turkey, 17100. Email: bcetin@comu.edu.tr

\section{REFERENCES}

Anderman, L.H.\& Freeman, T.M. (2004). Students' sense of belonging in school. In Pintrich P.R. \& Maehr, M.L. (Eds.), Motivating students, improving schools: The legacy of carol midgley (pp.27-63). Advances in motivation and achievement volume 13 Elsevier JAI: Amsterdam-Boston-Heidelberg-London-New York-Oxford-Paris- San DiegoSan Francisco-Singapore-Sydney-Tokyo.

Amrai, K Motlagh, S.E. , Zalani, H.A., \& Parhon, H. (2011).The relationship between academic motivation and academic achievement students. Procedia Social and Behavioral Sciences, 15, 399-402. Retrieved from http://www.sciencedirect.com/science/article/pii/S1877042811002904

Assor, A., Roth, G., \& Deci, E. L. (2004). The emotional costs of parents' conditional regard: A self-determination theory analysis. Journal of Personality, 72, 47-88. https://eds-b-ebscohost com.libez.lib.georgiasouthern.edu/eds/pdfviewer/pdfviewer?vid=2\&sid=244058f6-50f8-4e4a-ac78d133b5d3f6fd@sessionmgr112\&hid=117

Bandura, A. (1986). Social foundations of thought and action: A social cognitive theory. Englewood Ciffs, NJ: Prentice-Hall.

Bandura, A. (1997). Self-efficacy: The exercise of control. W.H. Freeman: New York: New York

Baumeister, R.F. \& Leary, M.R. (1995). The need to belong: Desire for interpersonal attachments as a fundamental human motivation. Psychological Bulletin, 117, 497-529.

Carolina, M., Lucia, R., Rossana, D.B. (2014). What Makes a Good Student? How Emotions, Self-Regulated Learning, and Motivation Contribute to Academic Achievement. American Psychological Association. doi: 10.1037/a0033546

Cokley, K.O., Bernard, N., Cunningham, D., \& Motoike, J. (2001). A psychometric investigation of the academic motivation scale using a united states sample. Measurement and Evaluation in Counseling and Development, 34, 109-119. Retrieved from https://eds-b-ebscohostcom.libez.lib.georgiasouthern.edu/eds/pdfviewer/pdfviewer?vid=3\&sid=764a094f-e0b0-4167-b3ea41b2c7c26409@,sessionmgr115\&hid=115

Deci, E. L. (1972). Intrinsic motivation, extrinsic reinforcement, and inequity. Journal of Personality and Social Psychology, 22, 113-120. Retrieved from http://selfdeterminationtheory.org/faculty?id=86

Deci, E.L. (1973). Intrinsic motivation (Technical Report 62). New York: Management Research Center University of Rochester. Deci, E.L. (1975). Intrinsic motivation: Conceptualizations of intrinsic motivation. Plenum Press: New York and London.

Deci, E. L., \& Ryan, R. M. (1985). Intrinsic motivation and self-determination in human behavior. Plenum Press: New York and London.

Deci, E. L., \& Ryan, R. M. (1995). Human autonomy: The basis for true self-esteem. In M.Kernis (Ed.), Efficacy, agency, and self-estem (pp.31-49). New York: Prenium. 
Deci, E.L\& Ryan, R.M (2002). An Overview of Self -Determination Theory: Organismic-Dialectical Perspective. In E.L.Deci \&R.M.Ryan (Eds.), Handbook of self-Determination Research (pp.3-33). The University of Rochester Press: Rochester, NY.

Deci, E. L., \& Ryan, R.M (2008). Self-determination theory: A macrotheory of human motivation, development and health. Canadian Psychology, 49, 182-185. Retrieved from http://selfdeterminationtheory.org/faculty?id=86

DiBenedetto, M.K.\& Zimmerman, B.J. (2013). Construct and predictive validity of microanalytic measures of students' selfregulation of science learning. Learning and Individual Differences 26, 30-41. http://dx.doi.org/10.1016/j.lindif.2013.04.004.

Ekhlas, N.N., \& Shangarffam, N. (2013).The relationship between determinant factors of self-regulation strategies and main language skills and overall proficiency. Procedia - Social and Behavioral Sciences, 70, $137-147$. Retrieved from http://www.sciencedirect.com/science? ob=ArticleListURL\& method=list\& ArticleListID $=-579516646 \&$ sort $=$ $\mathrm{r} \& \_\mathrm{st}=13 \&$ view $=\mathrm{c} \& \mathrm{md} 5=\mathrm{db} 7301 \mathrm{fe} 4 \mathrm{c} 5 \mathrm{fbda} 51 \mathrm{~d} 6 \mathrm{f} 3 \mathrm{add} 23 \mathrm{aec} 1 \mathrm{ef} \&$ searchtype $=\mathrm{a}$

Fraenkel, J.R., Wallen, N.E. (2006). How to design and evaluate research in education. Mc Graw Hill Higher Education. New York, NY.

Heikkilä, A. ve Lonka, K. (2006). Studying in higher education: students' approaches to learning, self-regulation, and cognitive strategies. Studies in Higher Education, 31,1,99-117. Retrieved from https://eds.b.ebscohost.com/eds/pdfviewer/pdfviewer?vid=3\&sid=4ea15f8e-b617-49d1-91ed12346a8644dc\%40sessionmgr111\&hid=101

Gagné, M., \& Deci, E. L. (2005). Self-determination theory and work motivation. Journal of Organizational Behavior, 26, 331 362. Retrieved from http://selfdeterminationtheory.org/faculty?id=86

Gaythwaite, E.S. (2006). Metacognitive Self Regulation, Self-Efficacy for Learning and Performance, and Critical Thinking as Predictors of Academic Success and Course Retention among community College Students Enrolled in Online, Telecourse, and Traditional Public Speakimg Courses (Unpublished doctoral dissertation). University of Central Florida, Orlando, Florida, USA.

Gay, L.R., Mills, G.E., Airasian, P., (2009). Educational Research competencies for analysis and applications. Pearson Education: New Jersey.

Lan, W. Y. (1998). Teaching self-monitoring skills in statistics. In D. H. Schunk \& B. J. Zimmerman (Eds.), Self-regulated learning: From teaching to self-reflective practice (pp. 86-105). New York: Guilford Press.

Lavender, M.M. (2005). A comparison of academic motivation of academically prepared and academically unprepared community college students (Unpublished doctoral dissertation). The Florida State University College of Education, Florida, USA.

Lodico, M.G., Spaulding, D.T., Voegtle, K.H. (2010). Methods in educational research from theory to practice. Jossey-Bass A Wiley Imprint: San Francisco

Komarraju, M., Karau, S.J., \& Schmeck, R.R.(2009). Role of the big five personality traits in predicting college students' academic motivation and achievement. Learning and Individual Differences, 19, 47-52. Retrieved from http://psychology.okstate.edu/faculty/jgrice/psyc4333/FiveFactor GPAPaper.pdf

Kim, E., \& Seo, E.H. (2013).The relationship of flow and self-regulated learning to active procrastination. Social Behavior and Personality, 41(7), 1099-1114. http://dx.doi.org/10.2224/sbp.2013.41.7.1099

Kosnin, A.M. (2007). Self-regulated learning and academic achievement in Malaysian undergraduates. International Education Journal, 8(1), 221-228. Shannon Research Press. Retrieved from http://files.eric.ed.gov/fulltext/EJ841762.pdf

Mahmoodi, M.H., Kalantarib, B., \&Ghaslanic, R. (2014). Self-Regulated Learning (SRL), Motivation and Language Achievement of Iranian EFL Learners. Procedia - Social and Behavioral Sciences 98, 1062 - 1068 .doi:10.1016/j.sbspro.2014.03.517.

Magno, C. (2010). Assessing academic self-regulated learning among filipino college students: The factor structure and Item Fit. The International Journal of Educational and Psychological Assessment, 5, 61-76. Retrieved from http://publicationslist.org/carlo.magno

Magno, C. (2011). The predictive validity of the academic self-regulated learning scale. The International Journal of Educational and Psychological Assessment, 9(1). 48-56 Retrieved from http://publicationslist.org/carlo.magno

McGhee, R.M.H. (2010). Asynchronous Interaction Online Technogies Self- Efficacy and Self Regulated Learning As Predictors of Academic Achievement In An Online Class. (Unpublished doctoral dissertation). The Faculty of the Graduate School Southern University and A \& M College, Baton Rouge, Luisiana, USA.

McMillan, J. (2008). Educational Research Fundamentals for the consumer. Pearson Education: Boston.

Ning, H.K. \& Downing, K. (2012). Influence of student learning experience on academic performance: the mediator and moderator effects of self-regulation and motivation. British Educational Research Journal. 38, 2, $219-237$. http://dx.doi.org/10.1080/01411926.2010.538468.

Niemiec, C.P; Ryan, R.M., \& Deci, E.L. (2010). Self-Determination Theory and the Relation of Autonomy to Self-Regulatory Processes and Personality Development. In Hoyle, R.H. (Ed.), Handbook of Personality and Self-Regulation (pp.169191). Wiley-BlackWell : United Kingdom. 
Özder, H., \& Motorcan, A. (2013). An analysis of teacher candidates' academic: Motivation Levels with Respect to Several Variables. British Journal of Arts and Social Sciences, 15, 1, 42-53 Retrieved from http://www.bjournal.co.uk/paper/BJASS 15 1/BJASS 15 01 04.pdf

Önder, I., Beşoluk, S., İskender, M., Masal, E., \& Demirhan, E. (2014). Circadian preferences, sleep quality and sleep patterns, personality, academic motivation and academic achievement of university students. Learning and Individual Differences. doi.org/10.1016/j.lindif.2014.02.003

Petri, H.L. (1981). Motivation: Theory and research. Beimont, CA: Wadsworth.

Pintrich, P.R.(2004). A Conceptual framework for assessing motivation and self-regulated learning in college students. Educational Psychology Review, 16, 4. 385-407. Retrieved from https://eds.a.ebscohost.com/eds/pdfviewer/pdfviewer?vid=4\&sid=34d69eeb-8bb4-4c3e-b405e3594d0708a9\%40sessionmgr4004\&hid $=4111$

Pintrich, P.R.; Schunk, D.H. (2002). Motivation in education theory, research, and applications. Upper Saddle River: New Jersey, Columbus, Ohio.

Pintrich, P.R.(2010). The role of goal orientation in self regulated learning. In M. Boekaerts, P.R. Pintrich \& M. Zeidner (Eds.), Handbook of self-regulation (pp.451-502). Academic Press: San Diego.

Robinson, N.M. (2003). Academic motivation and its relationship to personality variables and achievement (Unpublished doctoral dissertation). Southern Illinois University: Carbondale.

Rytkonen, H., Parpala, A., Lindblom-Ylanne, S., Virtanen, V., Postareff, L. (2012). Factors affecting bioscience students' academic achievement. Instr Sci, 40, 241-256. Doi 10.1007/s11251-011-9176-3.

Ratelle, C.F., Guay, F., Vallerand, R.J., Larose, S., Sene'cal, C. (2007). Autonomous, Controlled, and Amotivated Types of Academic Motivation: A Person-Oriented Analysis. Journal of Educational Psychology, Vol. 99, No. 4, 734-746. Retrieved from http://www.er.uqam.ca/nobel/r26710/LRCS/papers/ratetal2007.pdf

Schunk, D. H. (1987). Peer models and children's behavioral change. Review of Educational Research, 57, 149-174. http://libres.uncg.edu/ir/uncg/f/D_Schunk_Peer_1987.pdf

Schunk, D. H. (1989). Social cognitive theory and self-regulated learning. In Zimmerman, B.J. \&, Schunk, D.H. (Eds.), Selfregulated learning and academic achievement theory, research, and practice progress in cognitive development research (pp. 83-110). Springer-Verlag: New York Berlin Heidelberg.

Schunk, D. H.(1994). Self-regulation of self-efficacy and attributions in academic settings. In Schunk, D.H., \&, Zimmerman, B.J. (Eds.), Self-regulation of learning and performance: Issues and educational applications (pp. 75-99). Lawrence Erlbaum Associates: Hillsdale, New Jersey.

Schunk, D.H. \& Zimmerman, B.J. (2003). Self-regulation and learning. In Reynolds, W.M.\& Miller, G.E. (Eds.), Handbook of psychology Volume 7 Educational Psychology (pp.59-78). John Wiley \& Sons, Inc: New Jersey.

Schunk, D. H. (2005). Self-regulated learning: The educational legacy of Paul R. Pintrich. Educational Psychologist, $40,85-94$. Retrieved from http://libres.uncg.edu/ir/uncg/f/D_Schunk_Self_2005.pdf

Schunk, D.H. (2008). Learning Theories: An Education Perspective. Pearson Merrill Prentice Hall: New Jersey.

Schunk, D.H. \& Ertmer, P.A. (2010). Self-regulation and academic learning self-efficacy enhancing interventions. In M.Boekaerts, P.R. Pintrich \& M. Zeidner (Eds.), Handbook of self-regulation (pp. 631-649). Academic Press: San Diego.

Schraw, G., Crippen, K.J., \& Hartley, K. (2006). Promoting self-regulation in science education: Metacognition as part of a broader perspective on learning. Research in Science Education, 36, 111-139. Retrieved from http://www4.ncsu.edu/ jlnietfe/Metacog Articles files/Schraw,\%20Crippen,\%20\%26\%20Hartley\%20(2006).pdf

Schmidt, C.P., Zdzinski, S.F., \& Ballard, D.L. (2006). Motivation Orientations, Academic Achievement, and Career Goals of Undergraduate Music Education Majors. Journal of Research in Music Education. DOI: $10.1177 / 002242940605400205$.

Skinner, B.F. (1953). Science and human behavior. New York: Macmillan.

Vansteenkiste, M.; Lens, W., \& Deci, E.L. (2006). Intrinsic versus extrinsic goal contents in self-determination theory: Another look at the quality of academic motivation. Educational Psychologist, 41(1), 19-31. Retrieved from http://selfdeterminationtheory.org/SDT/documents/2006 VansteenkisteLensDeci_InstrinsicvExtrinsicGoal_EP.pdf

Vallerand, R. J., Pelletier, L. G., Blais, M. R, Brière, N. M., Senécal, C., \& Vallières, E. F. (1992). The academic motivation scale: a measure of intrinsic, extrinsic, and amotivation in education. Educational and Psychological Measurement, 52 , 1003-1017. Retrieved from http://www.selfdeterminationtheory.org/SDT/documents/1992_VallerandPelletierBlaisBriere_EPM.pdf

Vallerand, R.J., \& Bissonnette, R. (1992). Intrinsic, extrinsic, and amotivational styles as predictors of behavior: A prospective study. Journal of Personality, 60, 3, 599-620 Retrieved from https://eds-a-ebscohostcom.libez.lib.georgiasouthern.edu/eds/pdfviewer/pdfviewer?vid=3\&sid=f694384a-d6d0-42d8-b2cb5d1f6404fb52@sessionmgr4005\&hid=4111

Vallerand, R.J.; Losier, G.F. (1994). Self-determined motivation and sportsmanship orientations: An assessment of their temporal relationship. Journal of Sport \& Exercise Psychology, 16, 229-245. Retrieved from http://www.selfdeterminationtheory.org/SDT/documents/1994 VallerandLosier JSEP.pdf 
Vansteenkiste, M., Simons, J., Lens, W., Sheldon, K.M., Deci, E.L. (2004). Motivating Learning, Performance, and Persistence: The Synergistic Effects of Intrinsic Goal Contents and Autonomy-Supportive Contexts. Journal of Personality and Social Psychology, 87 (2), 246-260. Retrieved from http://selfdeterminationtheory.org/SDT/documents/2004 VansteenkisteSimonsLensSheldonDeci JPSP.pdf

Williams; G.C. \& Deci, E.L. (1996). Internalization of biopsychosocial values by medical students: A test of self-determination theory. Journal of Personality and Social Psychology, 70, 4, 767-779. Retrieved from http://selfdeterminationtheory.org/SDT/documents/1996 WilliamsDeci.pdf

Winne, P. H. (1995). Self-regulation is ubiquitous but its forms vary with knowledge. Educational Psychologist, 30(4), $223-228$.

Zimmerman, B.J.\& Schunk, D.H. (1989). Self-regulated learning and academic achievement: Theory, research, and practice. New York: Springer-Verlag.

Zimmerman, B.J. (1989). A Social cognitive view of self-regulated academic learning. Journal of Educational Psychology, 81, 3 , 329-339. Retrieved from https://eds.a.ebscohost.com/eds/pdfviewer/pdfviewer?vid=3\&sid=34d69eeb-8bb4-4c3e-b405e3594d0708a9\%40sessionmgr4004\&hid=4111

Zimmerman, B.J. (1990). Self regulated learning and academic achievement: An overview. Educational Psychologist, 25 (1), 3 17. Retrieved from http://www.rhartshorne.com/fall-2012/eme6507-rh/cdisturco/eme6507eportfolio/documents/zimmerman.pdf

Zimmerman, B.(1994). Dimensions of academic self-regulation: A conceptual framework for education. In Schunk, D.H.; Zimmerman, B.J. (Eds.), Self-regulation of Learning and Performance Issues and Educational Applications(pp.3-21). Lawrence Erlbaum Associates: Hillsdale, New Jersey.

Zimmerman, B. J., \& Paulsen, A. S. (1995). Self-monitoring during collegiate studying: An invaluable tool for academic selfregulation. In P. Pintrich (Ed.), New directions in college teaching and learning: Understanding self-regulated learning (No. 63, pp. 13-27). San Francisco: Jossey-Bass.

Zimmerman, B. (2001). Theories of self-regulated learning and academic achievement: An overview and analysis. In B.J. Zimmerman, \& D.H. Schunk (Eds.), Self Regulated Learning and Academic Achievement Theoretical Perspectives (pp.1-37). Routledge Taylor \& Francis Group: New York London.

Zimmerman, B, J. (2002). Becoming a self-regulated learner: An overview. Theory Into Practice, 41, 2, 64-70. Retrieved from http://commonsenseatheism.com/wp-content/uploads/2011/02/Zimmerman-Becoming-a-self-regulated-learner.pdf

Zimmerman, B.J., \& Schunk, D.H. (2004). Self regulating intellectual processes and outcomes: Social cognitive perspective . In D.Y. Dai, \& R.J. Stenberg (Eds.), Motivation, emotion, and cognition: Integrative perspectives on intellectual functioning and development (pp. 323-350). Mahwah, NJ: Erlbaum.

Zimmerman, B.J; Kitsantas, A. (2005). A. The hidden dimension of personal competence: Self-regulated learning and Practice. In A.J. Elliot, \& C.S. Dweck (Eds.), Handbook of Competence and Motivation (pp.509-526). The Guilford Press: New York London

Zimmerman, B.J. (2010). Attainment of self-regulation: A social cognitive perspective. In M.Boekaerts, P.R. Pintrich \& M. Zeidner (Eds.), Handbook of self-regulation (pp. 13-39). Academic Press: San Diego.

Zimmerman, B.J. (2011). Motivational sources and outcomes of self-regulated learning and Performance. In Schunk, D.H. \& Zimmerman, B.J. (Eds.), Handbook of Self-Regulation of learning and Performance (pp.49-64). Routledge Taylor \&Francis Group: New York and London.

Zimmerman, B.J. (2012). Goal setting: A key proactive source of academic self-regulation. In Schunk, D.H. \& Zimmerman, B.J. (Eds.), Motivation and Self-Regulated Learning Theory, Research, and Applications (pp.267-295). Routledge Taylor \&Francis Group: New York and London. 